\title{
Protection and Retaliation: Changing the 'Rules of the Game'
}

EVEN A QUICK PERUSAL of the daily paper suggests the controversial nature of international trade in the United States today. Canada and the United States are skirmishing over stumpage fees for lumber and support prices for corn. The European Community and the United States, having recently reached a truce in their grains and luxury edibles disagreement, are now arguing about airplanes and oilseeds. The United States and Japan are circling in round two of their semiconductor match. Germany and Switzerland refuse to restrain voluntarily their exports of machine tools to the United States. U.S. soybean producers demand a countervailing duty on Argentine soybean products because, they charge, Argentina's differential export tax encourages soybean production. Do these trade problems have a common foundation? Do the specific disputes threaten to escalate into broader-based conflicts involving more products or more countries? Can the historical record shed light on the causes and consequences of such trade arguments?

A major lesson of the past is that periods of macroeconomic stress in the United States have tended to precipitate changes in the conduct and implementation of U.S. trade policy. Those changes can then lead to escalating trade tensions and perhaps retaliation by the United States or by its trading partners. The focus in this paper is on changes in the conduct of U.S. policy primarily because the consequences of a change

This paper represents the views of the author and should not be interpreted as reflecting the views of the Board of Governors of the Federal Reserve System or other members of its staff. Many thanks to Eric Fisher and Charles Thomas, although they should not be held responsible for my eclectic approach to game theory. Thanks also to Ralph Tryon, Dale Henderson, Ellen Meade, Charles Siegman, and Peter Hooper. None of the above are responsible for errors. 
in the conduct of the largest trading nation are probably greater than the consequences of any policy changes by other trading nations. Moreover, in the past two years, the United States arguably has changed its approach to trade policy to a relatively greater degree than other countries have changed theirs.

The worst era of U.S. macroeconomic stress and changes in trade policy was 1929-31. Although macroeconomic problems in that era were far more pressing than the problems today, both periods are similarly characterized by severe macroeconomic imbalances, a Congress (with its regional constituency) relatively stronger than the president (with his national constituency), and policymakers who perhaps incorrectly ascribe to trade policy the ability to restore macroeconomic equilibrium. In 1930 these three factors working together produced the Smoot-Hawley Tariff Act. Tariffs were increased on thousands of products, with the average tariff rate on dutiable imports rising 13 percentage points to 53 percent from 1929 to 1931 . Between 1980 and 1986, these three factors contributed to a more than doubling of the number of countervailing duty and antidumping cases, from 93 cases in 1980 to 197 cases in 1985, and a quadrupling of "unfair" foreign trade practices cases, from 11 in 1980 to 42 in 1986.

Not all historical periods characterized by these three economic and political factors have suffered the apparent breakdown of international consensus about the conduct of trade policy that produces retaliation. In 1922, the Fordney-McCumber Act raised average U.S. tariff rates 9 percentage points to 38 percent. Yet U.S. trading partners did not retaliate against this tariff hike as they did against the Smoot-Hawley tariffs. In the 1960s and 70s, the United States and the European Community skirmished over steel, chickens, pasta, and citrus without the specter of Smoot-Hawley appearing in the diplomatic and popular press alike.

The critical fourth characteristic common to the Smoot-Hawley period and today is the view of U.S. trading partners that U.S. actions are either unjustified within the consensual code of international behavior or unexpected given the past behavior of the United States in international trade negotiations. In 1930, the United States failed to play by the established rules of the game: it indiscriminately increased many tariffs with no apparent domestic objective, and it imposed sweeping tariffs when it enjoyed a balance of payments surplus. During the 1980s, the 
United States changed its interpretation of the rules of the game: it has widened the scope of foreign policies that elicit offsetting duties, and it has increasingly used trade threats against one industry to extract trade concessions in another industry. Faced with such radical changes in established U.S. trade behavior, other countries may agree to negotiate on the new terms, or they may decide not to negotiate and instead may retaliate.

A simple game-theory payoff matrix in which two countries can choose to negotiate to open markets or retaliate and close markets will help in analyzing such a situation. For example, macroeconomic stress changes the political and economic benefits of pursuing an open markets trade policy, thus changing elements of the payoff matrix. If the United States increases the range of foreign policies that elicit offsetting penalties or penalizes one industry for infractions in another, it also changes the payoffs in the matrix. When the United States changes its established behavior by threatening to impose penalties, U.S. trading partners must decide whether to believe the threat. The effect is to reduce the confidence of the trading partner in the payoffs in the old matrix versus the payoffs in the new matrix. The magnitude of the change in the payoffs and the likelihood that these changes reflect a new strategy are both critical determinants of whether countries end up in a trade war with closed markets or decide to negotiate and open markets.

The structure of the paper is as follows. First, I detail the features of the macroeconomic, political, and institutional landscape common to the Smoot-Hawley era and the present. That examination suggests a set of stylized facts about the political and economic gains or losses of following a particular trade policy strategy. Ialso describe the similarities and differences between the League of Nations and the General Agreement on Tariffs and Trade (GATT) for their codifying of the rules of the game and for their dispute-settlement procedures, and I suggest the extent to which these differences may contribute to a reduced likelihood of a trade war today.

Then I show how a set of simple game-theory payoff matrices can provide a framework for these stylized facts. The model suggests that retaliation was not a necessary result of the Smoot-Hawley tariffs, nor would it be a necessary consequence of U.S. protectionism today. The analysis further points out what factors may be important contributors to a negotiated outcome, instead of a round of retaliation. 
Finally, I discuss incidents of retaliation for the Smoot-Hawley bill and analyze some cases of protection and retaliation from the 1980s. This event analysis fits the hypotheses generated by the game-theory analysis.

\section{Smoot-Hawley Era and the 1980s}

In terms of severity, global reach, and depth of economic dislocation, there is little comparison between the macroeconomic problems of the 1930s and those of the 1980s. Nevertheless, relative to recent historical experience, the macroeconomic imbalances of the 1980s are severe, especially from the viewpoint of the United States. Moreover, most economists believe the proximate causes of the macroeconomic imbalances in both eras to be macroeconomic in nature. Yet, in both periods, policymakers turned to trade policy to provide at least a partial solution to the macroeconomic problems.

\section{MACROECONOMIC ENVIRONMENT}

Between 1929 and 1931, price deflation and unemployment were the most severe problems confronting the nation. Agricultural prices fell 50 percent, while unemployment rose from 3.2 percent to 15.9 percent. Many economists argue that the cause of the Depression was monetary restraint combined with fiscal inaction. But at the time, the policymakers' solution to the problems of deflation and unemployment was to raise domestic prices and redirect demand towards domestic producers by increasing tariffs. For the Republican party, then in office, the tariff was the "household remedy." Moreover, as F. W. Taussig notes, "All the popular debates of the last generation . . . inculcated the belief that the mere imposing of a duty served at once to benefit the domestic producer. . . . The rank and file welcome[d] immediate and drastic tariff charges." "Unfortunately, prohibitive tariffs imposed by all countries drive trade to zero. ${ }^{2}$ Thus the Smoot-Hawley Tariff Act, along with

1. F. W. Taussig, in Heinrich Liepmann, Tariff Levels and the Economic Unity of Europe (MacMillan, 1938), p. 225.

2. The original article discussing optimal tariffs and retaliation is Harry G. Johnson, “Optimum Tariffs and Retaliation," Review of Economic Studies, vol. 21, no. 2 (1953), 
retaliation and other economic dislocations of the time, achieved exactly the opposite of what policymakers had hoped. Agricultural prices continued to slide, and the unemployment rate rose to 24.9 percent by 1933.

In the 1980s, the massive current account deficit in the United States is the key imbalance. Causes include the large U.S. fiscal budget deficit and a relatively low U.S. personal saving rate. The Gramm-RudmanHollings deficit reduction law attempts to target the macroeconomic imbalance at its source. But the omnibus trade bills currently under consideration in Congress focus on righting the trade imbalance through trade policy actions such as imposing surcharges on imports from trading partners that enjoy large bilateral credit balances and linking U.S. imports of certain countries' products to U.S. export performance in their domestic markets.

A second force behind use of the tariff in the 1930s was real exchange rate variability. Under the notion of the "scientific tariff," the appropriate tariff was the one that equalized the costs of production at home and abroad. As the Depression deepened, postwar gold parities broke down, and even Britain left the gold standard. In the ensuing "currency warfare . . . tariffs became a very important weapon . . . in meeting the competition of the European and overseas devaluation countries." 3

In the 1980s real exchange rate variability has likely been one of the causes of increased trade complaints by U.S. industries. As the dollar appreciated, U.S. companies petitioned for emergency protection from import surges. Other companies charged foreign importers with pricing below cost of production or sales price in their home markets through the countervailing and antidumping (CV/AD) statutes. The CV/AD caseload more than doubled from 1980 to 1985 . As the dollar depreciates, the number of $\mathrm{CV} / \mathrm{AD}$ cases is rising as foreigners cut profit margins and prices on goods sold into the U.S. market in an effort to maintain their

pp. 142-53. Johnson shows that two large countries with elastic offer curves will drive trade to zero if they both try to impose optimal tariffs. However, if one of the offer curves has an inelastic portion, trade will not go to zero. Kiyoshi Kuga, "Tariff Retaliation and Policy Equilibrium," Journal of International Economics, vol. 3 (November 1973), pp. 351-66, presents this argument more formally. Carlos Alfredo Rodriguez, "The Nonequivalence of Tariffs and Quotas under Retaliation," Journal of International Economics, vol. 4 (August 1974), pp. 295-98, examines quotas and retaliation, finding the same basic result.

3. Liepmann, Tariff Levels, p. 362. 
market shares in the United States. Projected at an annual rate, the 79 cases filed between January and April this year suggest a further increase of 20 percent over the 1985 caseload.

Another similarity between the 1930s and the present is the magnitude of some countries' external debts and the concomitant pressures on them to reduce their imports in order to repay these debts. In the 1930s German war reparations (had they been paid) ranged up to 50 percent of exports. In the 1980s, the pressures on the Latin American debtors to reduce their imports exacerbated the U.S. current account deficit. In 1980, U.S. exports to Latin America accounted for 17 percent of export volume. By 1985, that share had dropped to 14 percent.

\section{POLITICAL ENVIRONMENT IN THE UNITED STATES}

Historically, Congress has presided over changes in tariff rates because of its constitutionally mandated power to levy taxes. However, over the decade before Smoot-Hawley, Congress delegated some of its tariff authority to the president. Believing that the pace of technological progress, and therefore the decline in foreign prices, was too quick for each specific tariff case to be submitted to legislative review, Congress passed the Fordney-McCumber Tariff of 1922 to give the president authority to adjust tariffs on specific commodities up or down as much as 50 percent. The president could raise (or lower) a tariff on a specific product to equalize the domestic and foreign costs of production as calculated by the nonpartisan Tariff Commission, the predecessor to the International Trade Commission. In fact, the president made only thirtyseven changes in specific tariffs, of which thirty-five were increases, between 1922 and $1930 .{ }^{4}$

As the economic dislocation of the Depression deepened and prices continued to fall, Congress reasserted its right over the specifics of tariff policy and produced the Smoot-Hawley Tariff Act. Initially a bill to increase agricultural tariffs, Smoot-Hawley could not have passed had the agricultural interests not formed a coalition with certain manufacturers. ${ }^{5}$ Eventually, the bill engendered 20,000 pages of testimony covering

4. Asher Isaacs, International Trade: Tariff and Commercial Policies (Chicago: Richard D. Irwin, 1948), p. 255.

5. Barry Eichengreen, "The Political Economy of the Smoot-Hawley Tariff," Working Paper 2001 (National Bureau of Economic Research, August 1986), p. 18. Forthcoming in Research in Economic History. 
25,000 products. An example of the remarkable detail in the bill is cork, for which there were eighteen different tariff rates. ${ }^{6}$ After Smoot-Hawley passed, dutiable imports rose from 34 percent of total value of imports in 1929 to 48 percent in 1931. Average duty rates on dutiable imports rose from 39 percent in 1929 to 53 percent in 1931 to 59 percent in $1932 .{ }^{7}$

Today Congress is again asserting its mandate to direct trade policy. Characteristics of Smoot-Hawley common to the current House and Senate omnibus trade bills include special treatment for a number of specific industries and restrictions on the president's discretionary powers over trade policy decisions. The omnibus trade bills contain articles limiting the right of the president to veto trade protection for industries that have received an affirmative judgment of injury by the International Trade Commission. Other articles would require the president to retaliate against the imports of countries if the ITC determines that they use unfair trade practices to restrict U.S. exports. Unfair trade practices are defined very broadly, ranging from domestic "market reservation" policies to targeting "traditional" U.S. overseas markets. Moreover, amendments to the omnibus trade bills single out new industries, such as titanium and telecommunications, for special treatment.

\section{INSTITUTIONAL ENVIRONMENT}

Today, as in the 1930s, multilateral forums exist for the discussion of international trade problems. In the late 1920s and early 1930s the League of Nations sponsored several meetings to discuss and try to limit tariff increases. But the meetings were oriented more toward crisis management and arresting the unraveling international trade situation in Europe than toward reestablishing the consensus about the circumstances under which countries could apply protectionist policies and about what should be the overall characteristics of protectionist policies if such were deemed necessary. Today, the GATT principles represent a general consensus on the international rules of trade policy behavior. Perhaps because the GATT principles are relatively clear, even if their implementation is woefully vague, there is hope that the GATT Uruguay Round currently being held in Geneva will be more successful at

6. Isaacs, International Trade, pp. 239-40.

7. Eichengreen, "The Political Economy of the Smoot-Hawley Tariff," table 3. 
preventing an escalating trade war than was the League of Nations Convention of March 1930.

The World Economic Conference of 1927, attended by representatives from fifty nations, unanimously concluded that "the time has come to put a stop to the growth of customs tariffs and to reverse the direction of movement." 8 As the business cycle turned in 1929, the Economic Committee of the League of Nations noted with great concern that "in spite of a few sporadic efforts no decisive movement has occurred in this direction." ${ }^{9}$ It called for a two-year tariff truce. Thirty nations sent delegates with negotiating authority, and seven nations sent observers, to the March 1930 convention, which produced a draft agreement stating that signatories would not abrogate their existing commercial treaties for at least two years and would increase tariffs only in the case of an undefined domestic emergency. But the draft text was never put into effect. An escalating round of tariff increases was under way; nothing could stop it.

One of the factors that may help prevent escalating retaliation today is the GATT. The GATT articles, signed by nearly one hundred nations, with more still joining, are vaguely worded, cannot be enforced, and are critically uncomprehensive in both the range of trade issues addressed and solutions allowed. Nevertheless, simply by weight of numbers, GATT represents a consensus on what most believe should be the guiding principles of external policy. Protection must be nondiscriminatory and should be based on a price mechanism that is limited in time and scope; countries must compensate their trading partners if they invoke emergency protection; and GATT contracting parties agree to bring trade disputes to GATT, even if results of the committee deliberations cannot be enforced.

However, interpreting and implementing the principles are quite difficult, especially when doing so causes a nation's domestic and external policy objectives to conflict, as they do in the most contentious issues in the drafting of the agenda for the Uruguay Round-services trade, agricultural subsidies, and intellectual property rights.

To sidestep some of the principles and obligations of GATT, members turn to policies that are not within the spirit, although they are not

8. Liepmann, Tariff Levels, p. 348.

9. Ibid. 
explicitly outside the letter, of GATT. Market reservation schemes, nontariff barriers, and voluntary restraint agreements on exports are several examples. These policies are derogations from the GATT principles, and they weaken the established GATT consensus, maintaining which may be key to avoiding an escalating round of tariff retaliation.

Once Congress responds to mounting concern about trade by changing the conduct and implementation of U.S. trade policy and by deviating from the established international rules of the game, U.S. trading partners are necessarily confused about the future course of U.S. trade policy. They may not understand why the United States is now complaining about or even retaliating against policies that heretofore had been acceptable. Once the largest trading partner decides to play with a different set of rules, other countries can similarly reinterpret the rules to their advantage. The consequences of trading partners failing to agree on the rules are confusion, threats, and perhaps retaliation.

\section{Game Theory and Trade Protection}

A simple game-theory model will help show how a change in one country's attitude toward protection and a corresponding change in the perceptions of that country's trading partners that it has changed its trade policy strategy could lead either to negotiation that opens markets to trade or to retaliation that closes markets. ${ }^{10}$ The model is only a simple presentation of the stylized facts using a game-theory paradigm. Virtually all the difficult aspects of the solution are saved for another paper, and I ignore the technical aspects of game theory that would stand in the way of this simple presentation.

10. Marie Thursby and Richard Jensen use a conjectural variation approach to analyze how the magnitude of an optimal tariff changes with an increase in the likelihood of retaliation. See Marie Thursby and Richard Jensen, "A Conjectural Variation Approach to Strategic Tariff Equilibria," Journal of International Economics, vol. 14 (February 1983), pp. 145-61. They find that an increased likelihood of retaliation by one player decreases the tariff that is optimal for the other player to apply. Raymond Riezman, "Tariff Retaliation from a Strategic Viewpoint,"' Southern Economic Journal, vol. 48 (January 1982), pp. 583-93, considers an equilibrium where two players negotiate tariffs. The negotiated tariffs lie between the optimal tariff rates of the two players. The relative size of the two actors is key to the magnitude of the negotiated tariffs; the larger player's tariff is closer to its optimal tariff. 
As the payoff matrix displayed opposite shows, the two countries $A$ and $B$ can choose two strategies, negotiate $(N)$ or retaliate $(R)$. The negotiation strategy is one by which the countries reduce tariffs and open their markets to trade; the retaliation strategy increases tariff rates and closes markets to trade. The elements of the cells show the payoffs, which could be measured in utility terms, that each country obtains at the equilibrium of their joint strategies. ${ }^{11}$ For example, if the equilibrium results in each country negotiating and opening its markets, country $A$ obtains $A^{N N}$ units of utility and country $B$ obtains $B^{N N}$ units of utility. If the equilibrium results when country $B$ negotiates and country $A$ retaliates, then the payoffs are shown in the southwest cell, where country $A$ obtains $A^{R N}$ units of utility and country $B$ obtains $B^{R N} .^{12}$

11. We could think of payoffs in the matrices coming from a social welfare function where the payoff from pursuing any particular strategy is a function of macroeconomic events and trade policy lobbying activity. One strand of the economics literature focuses on this latter point of lobbying and the political economy of tariff formation. A good overview piece on this topic is Robert E. Baldwin, "The Political Economy of Protectionism," in Jagdish N. Bhagwati, ed., Import Competition and Response (University of Chicago Press, 1982), pp. 263-86. For papers that examine in more detail the outcome of lobbying behavior where politicians and workers play a game against each other to determine the magnitude of a protective tariff, see Stanislaw Wellisz and John D. Wilson, "Lobbying and Tariff Formation: A Deadweight Loss Consideration," Journal of International Economics, vol. 20 (May 1986), pp. 367-75; Ronald Findlay and Stanislaw Wellisz, "Endogenous Tariffs, the Political Economy of Trade Restrictions, and Welfare," in Bhagwati, ed., Import Competition, pp. 223-43; Wolfgang Mayer, "Endogenous Tariff Formation," American Economic Review, vol. 74 (December 1984), pp. 970-85; and Robert C. Feenstra and Jagdish N. Bhagwati, "Tariff Seeking and the Efficient Tariff,"' in Bhagwati, ed., Import Competition, pp. 245-61. Both players weigh political and economic costs and benefits, and in some cases consider the welfare effects to the nation as a whole of applying a tariff. Mayer returns to first principles to examine how ownership of capital and labor, factor mobility, and industry diversification affect the negotiated tariffs.

12. Two articles that explicitly acknowledge the role of retaliation in the tariff formation process are Wolfgang Mayer, "Theoretical Considerations on Negotiated Tariff Adjustments,"' Oxford Economic Papers, vol. 33 (March 1981), pp. 135-53; and Richard Baldwin, “'Optimal Tariff Retaliation Rules"' (Columbia University, November 1986). Mayer's paper focuses mainly on optimal tariffs and retaliation in the case where players are of different economic sizes. But he does consider the implication for the home country's tariff choice if there are domestic lobbying groups of different size and strength. Baldwin focuses on how the likelihood of retaliation in export markets should affect the lobbying activity for tariff protection in the home market. He assumes that firms produce for both domestic and overseas sales. 


\begin{tabular}{ccccc}
\multicolumn{4}{c}{ Country $B$} \\
& \multicolumn{2}{c}{$N$} & \multicolumn{2}{c}{$R$} \\
\cline { 3 - 4 } Country $A$ & $N$ & $A^{N N}, B^{N N}$ & $A^{N R}, B^{N R}$ \\
\cline { 3 - 4 } & $R$ & $A^{R N}, B^{R N}$ & $A^{R R}, B^{R R}$ \\
\cline { 3 - 4 } & & &
\end{tabular}

Equilibrium in any particular cell may result either from a cooperative decision to pursue particular strategies or from failure to cooperate. For example, the payoffs shown below yield a noncooperative equilibrium in the closed markets corner of the matrix, the southeast corner, in which both countries (in this case Europe and the United States) lose 4 units of utility. If these two countries cooperated, they could reach a negotiated outcome, in which each obtains 1 unit of utility. ${ }^{13}$

\begin{tabular}{|c|c|c|c|}
\hline & & $U n$ & States \\
\hline & & $N$ & $R$ \\
\hline оре & $N$ & $1, \quad 1$ & $-5, \quad 2$ \\
\hline & $R$ & $2,-5$ & $-4,-4$ \\
\hline
\end{tabular}

The above matrix could represent payoffs faced by Europe and the United States during the Smoot-Hawley period. The United States believed that closing its markets would increase domestic demand, leading to a higher payoff than would free trade $\left(U^{N N}=1\right.$ while $U^{N R}=$ 2). However, once the United States chooses the closed markets strategy, Europe minimizes its losses by also choosing the closed markets strategy. (If the United States chooses $R$, Europe loses 5 units if it chooses $N$ and loses 4 units if it chooses $R$.) There is no way in this oneshot game to avoid the worst-case outcome.

But suppose neither Europe nor the United States had full information regarding the payoffs. For example, suppose the payoffs from choosing the open markets strategy is some weighted average of gain 1 unit and gain 3 units. In other words, both the United States and Europe might have weighted the gains from trade too lightly, perhaps because of political pressures from lobbying groups. The matrix that follows shows

13. Cooperation cannot be sustained in the one-shot game presented here. Trade policy is a natural application for the repeated game format, but I have not chosen that technique here because I wish to focus more on the problem of uncertainty. 
this structure, where $Q$, the weight, is assumed for simplicity to be equal for the United States and Europe.

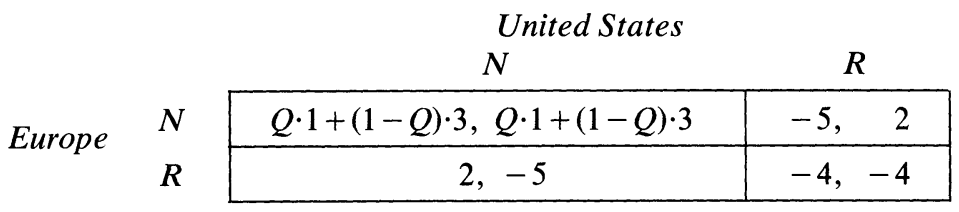

For any $Q$ less than 0.5 , the expected payoff to cooperating would be greater than 2 for each country if both chose negotiation and free trade $(N)$. In this case, neither would be tempted to leave that outcome, for the $R$ strategy promises a worse outcome whatever the other side might do in return. Thus this analysis suggests that uncertainty regarding payoffs is important in determining the outcome of trade negotiations.

Consider now the present-day situation. Instead of focusing on uncertainty regarding the payoffs, I will examine the effect of uncertainty facing U.S. trading partners with regard to the overall conduct of U.S. trade policy. Suppose the other country is Japan, and payoffs are shown below. The left-hand matrix displays payoffs before about $1985 .{ }^{14} \mathrm{Given}$ the payoffs displayed in that matrix, the noncooperative equilibrium is in the southwest corner. An equilibrium in the southwest corner might result from a U.S. political utility function in which the moral imperative of maintaining a liberal trading environment exceeds any economic losses associated with Japan's strategy of closed markets. This result could come from a variety of different weights on moral benefits versus economic costs in the utility function.

Before 1985

United States

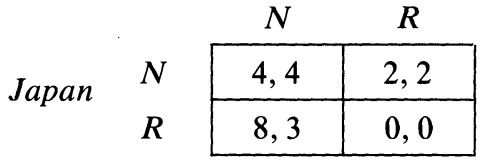

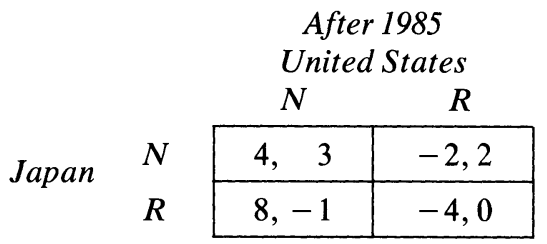

Suppose now that for the United States the balance between moral benefits and economic costs of pursuing a free trade policy has changed over the past several years, thus affecting the entries in the matrix. The large current account deficit increases the political and economic con-

14. In 1985 the president initiated his trade policy "Strike Force" and the House and Senate started work on a new trade bill. 
sequences of maintaining a liberal trading environment, and reduces the utility obtained by being a free trader. This change may reduce the payoff to the United States associated with a negotiation strategy ( $U^{N N}$ falls from 4 to 3 , and $U^{R N}$ falls from 3 to -1 ). Congress has also made it easier for U.S. industries to obtain injury judgments and protection and to impose penalties for dumping, a change that increases the penalty facing Japan if the United States retaliates ( $J^{N R}$ changes from 2 to -2 , and $J^{R R}$ falls from 0 to -4 ). The right-hand matrix shows values consistent with these stylized facts.

The key question is whether the change in the conduct of U.S. trade policy, as parameterized by values in the post-1985 payoff matrix, will change Japan's trade policy from a closed markets strategy to an open markets strategy. Will uncertainty about whether U.S. policy has in fact changed cause Japan to underestimate the expected value of the open markets strategy, choose the closed markets strategy, and force the United States into a trade war? The answers to these questions depend on whether the United States can credibly threaten to retaliate if Japan chooses the retaliation strategy, what probability Japan assigns to the likelihood that the post-1985 matrix accurately reflects U.S. payoffs, and the magnitude of the difference between Japan's positive payoff if it negotiates and its penalty if it chooses a retaliation strategy and the United States retaliates as well.

Changing the payoff $U^{R N}$ from 3 in the pre-1985 matrix to -1 in the post-1985 matrix creates a credible threat; it is no longer in the U.S. interest to negotiate regardless of Japan's strategy. If Japan chooses the retaliation strategy, then the United States will choose that strategy as well. Japan will lose 4 units of utility, while the United States will get a zero payoff. However, this credible threat is effective in getting Japan to change policies to the open markets strategy only if Japan puts enough weight on payoffs in the post-1985 matrix. Therefore, it is a combination of the magnitude of the change in payoffs and Japan's belief about the state of thinking in the U.S. Congress that determine whether the negotiation or retaliation equilibrium results.

Let the perceived probability that the United States has not changed its payoffs of conduct be given by $\boldsymbol{P}$. Then $\boldsymbol{P}$ equals Japan's belief that the pre-1985 matrix accurately reflects the payoffs associated with U.S. trade policy and so will dictate U.S. conduct. Calculate the expected payoffs for Japan assuming that the United States chooses strategies as 
represented in the two matrices. If Japan chooses a negotiation strategy, its expected payoff is

$$
N=P \cdot J_{p r e}^{N N}+(1-P) \cdot J_{p o s t}^{N N}=P \cdot 4+(1-P) \cdot 4=4 .
$$

If Japan maintains the closed markets strategy, its expected payoff is

$$
R=P \cdot J_{p r e}^{R N}+(1-P) \cdot J_{p o s t}^{R R}=P \cdot 8+(1-P) \cdot(-4)=12 P-4 .
$$

Where $P$ equals $2 / 3$, the expected value of the negotiation strategy equals the expected value of the retaliation strategy. If $P$ is greater than $2 / 3$, then Japan will keep the closed markets strategy, the United States will change to that strategy, and the retaliation-trade war equilibrium obtains. But, for any $P$ less than $2 / 3$, the expected value of the negotiation strategy is greater than the expected value of the retaliation strategy. Japan will choose the open markets strategy, and the United States will do likewise. The United States is better off than it was in the equilibrium strategy in the pre-1985 matrix, although Japan is not as well off. But both are better off than they would be under the retaliation-retaliation strategy in the post-1985 matrix.

What can the United States do to get Japan to choose the negotiation strategy? It can increase Japan's conviction that the post-1985 matrix represents the true payoffs and strategies-that is, increase the threat of retaliation. Or it can increase the penalties of the retaliation-retaliation equilibrium, which will also raise the value of $P$ required to make Japan choose the negotiation strategy. ${ }^{15}$ The posturing in Congress, the threats of retaliation, the stricter application of trade laws, and the actual incidents of retaliation by the United States are ways of communicating changes in the values of the payoffs, thus informing trading partners that they should not look back at the old game, but forward to the new game.

As this simple example points out, it is not clear that the outcome for either or both countries is superior to that obtained before the United States changed its conduct, the outcome associated with the pre-1985 matrix. The $U^{N N}$ element in the post-1985 matrix is the same as $U^{R N}$ in the pre-1985 matrix. But it is clear that the open markets strategy is superior within the confines of the payoffs in the post-1985 matrix. Therefore, the uncertainty about whether U.S. conduct has in fact

15. In a repeated game framework, we could think of a set of payoff matrices, each representing an update on what Japan believes are the payoffs. 
changed is critical for the correct choice of trade strategy by the trading partner. That is why when the largest trading nation changes the way it plays the game, confusion and retaliation may result, at least until the rules of the new game are known to all.

\section{Retaliation}

The model suggests that the retaliation equilibrium, in which both countries pursue a trade strategy that closes markets, is more likely when the losses due to that outcome are small or are weighted too lightly by the second country when it tries to determine whether the first country's trade strategy has changed. Both the historical record on retaliation after Smoot-Hawley and the trade disputes currently under way support this hypothesis.

\section{SMOOT-HAWLEY PERIOD}

Not all the tariff increases in Europe and Latin America during the 1930s can be attributed to the Smoot-Hawley tariff. As already noted, the League of Nations convened a conference to discuss tariff increases in Europe well before Smoot-Hawley was even in committee. Although distinguishing between retaliatory trade actions and ones that a country would have taken anyway is difficult, I will present three examples in which the timing and the specificity of the actions suggest retaliation. A key theme of these cases is that these countries retaliated because they felt that the U.S. tariff action against them was a violation of the established code of international behavior.

During the 1920s and 1930s, many politicians and economists felt that international flows of gold, as well as of credit, determined domestic and international growth and stability. When the price-specie flow mechanism works as it should, surplus countries gain gold supplies leading to increases in domestic wages and prices. Rising wages and prices in turn increase absorption and reduce competitiveness, yielding gold flows out of the country. If gold flows are restricted by limiting trade, deficit countries cannot achieve rising income, prices, and wages.

The Smoot-Hawley tariff undermined the workings of this mechanism by restricting U.S. imports when the United States was enjoying a 
balance of payments surplus. ${ }^{16}$ Some U.S. politicians even hoped that Smoot-Hawley would return the country to autarchy. As other countries saw it, the United States was trying to reduce permanently the gold supply in circulation, yielding further declines in prices and activity in the deficit countries. Asher Isaacs reports that Italian editorials charged the United States with "attempting to corner the gold supply and ruin the entire world, especially Italy." 17

Another element of the established code of international trade conduct was that tariffs could be applied to protect domestic industry. But the Smoot-Hawley tariffs also hit innumerable products that the United States did not, or in some cases could not, produce. As Isaacs protested, "Many of the items are not competitive with American items because they come from different climates or resources not found in this country. . . . Few, if any, can be regarded as competing with products of American 'infant' industries. On the other hand, many of these products are vital to the protesting countries since they constitute important export items." 18 The 1,000 percent increase in the tariff on cashew nuts was, said Isaacs, quoting cables from India, "unjustified whilst United States not producing cashews. [The] cashew industry in British India will be destroyed." 19

U.S. trading partners watched the Smoot-Hawley bill barrel through Congress, becoming more far-reaching by the day. More than 1,000 economists warned of the dangers of retaliation and the consequences to economic activity of a world trade war. Some thirty-five countries sent official cables threatening retaliation should the bill become law. Some of the foreign cables were diplomatically worded, others more strident. The Japanese government cabled, “Japan's purchasing power is in a large measure derived from her exports, especially those to the United States. Any decrease in her exports to the United States, therefore, cannot but reduce her demand for American products." 20 France cabled that there were "protests . . . on the part of numerous

16. In fact, Eichengreen, "The Political Economy of the Smoot-Hawley Tariff," hypothesizes that Smoot-Hawley probably worsened the Depression more through its influence on the international financial system than through anything else.

17. Isaacs, International Trade, p. 236.

18. Ibid., p. 231.

19. Ibid.

20. Ibid., p. 232. 
groups of exporters and manufacturers [because the] minimum French tariff has been granted to almost all American merchandise without the slightest corresponding advantage having been obtained for French trade." 21 When the Smoot-Hawley bill became law, some countries, including Spain, Italy, and Canada, retaliated by selectively imposing tariffs on U.S. exports; others, including Italy, required a zero bilateral trade balance; still others, including Canada, removed U.S. products from most-favored-nation status.

In 1929 the United States imported 57 percent of the entire cork output of Spain. When a combination of tariff and nontariff barriers cut U.S. imports of Spanish cork to zero, Spain retaliated by increasing tariffs on U.S. assembled autos 100 to 150 percent. To avoid transshipment of unassembled autos through Europe, Spain taxed those as well. Duties on other manufactured products in which the United States enjoyed a comparative advantage, such as sewing machines, motorcycles, and razor blades, also rose substantially, as much as 700 percent in the case of the razor blades. Moreover, the Spanish market for U.S. exports was ruined, as France "within six weeks sent a brilliant crew of commercial experts to negotiate a treaty with Spain [such that] France found herself enjoying preferential treatment on practically all the commodities which our exporters lost." 22

In Italy U.S. auto exports were a retaliatory target for Smoot-Hawley tariffs on ships, marble, and textiles. "Un-heard of duties" stopped car imports, and Ford closed its assembly plant. In addition, "Italian drivers [of American cars] were embarrassed and annoyed by having their tires punctured. . . . The Royal Automobile Club of Italy wanted to publicize the names of all Italians buying American cars." Mussolini said, "We will buy in the United States only the amount of goods equivalent to the amount of goods the United States will buy in Italy." Exports from the Soviet Union to Italy rose from \$18 million in 1929 to $\$ 29.5$ million in 1931, during a time when world trade value fell in half, suggestive of who replaced the U.S. exporters in the Italian market. ${ }^{23}$

The Smoot-Hawley bill targeted Canadian products from all provinces. Moving from east to west, Smoot-Hawley increased tariffs on

21. Ibid.

22. Ibid., p. 235.

23. Ibid., p. 236. 
halibut, dairy products, potatoes, cattle, grains, apples, and lumber. To retaliate, Canada raised tariffs on 125 U.S. products. She expanded British preference and explicitly discriminated against certain U.S. exports. Chemicals from England were duty-free, chemicals from other countries entered with a 10 percent duty, but U.S. chemicals got slapped with a 25 percent surcharge. ${ }^{24}$

Taking this historical evidence and applying it to the game-theory paradigm may reveal broad generalities about possible influences on U.S. policymakers that induced them to pass the Smoot-Hawley bill even in the face of threats of retaliation. In the game-theory paradigm, the United States chooses the closed markets strategy when the political rewards outweigh possible economic losses of the strategy. Certainly politicians of the constituents benefitting from high Smoot-Hawley tariffs saw political benefits and may have expected economic benefits as well. Moreover, the closed markets-retaliatory outcome is more likely the lower the probability the United States puts on the likelihood of a retaliation strategy being pursued by its trading partners. Perhaps the United States underestimated the likelihood of retaliation by other countries, despite the cables. The United States probably also underestimated the economic losses resulting from retaliation. Given these beliefs, the worst-case closed markets outcome resulted.

As trade volume and domestic welfare continued to fall to the trough of the Depression, the closed markets philosophy increasingly came under fire. The denouement of Smoot-Hawley was the Reciprocal Trade Agreements Act of 1934, the stated goal of which was to "expand foreign markets and regulate imports." ${ }_{25}$ But, more important, Congress authorized the president to negotiate bilateral and reciprocal tariff treaties. Country-by-country the United States would try to negotiate the open markets strategy in the hopes of achieving the beneficial outcome that clearly had not been attained through the closed markets strategy.

THE 1980S

In the Smoot-Hawley era, the United States had to analyze the likelihood of retaliation and the magnitude of the losses should retaliation

24. Ibid., p. 237.

25. Ibid., p. 251. 
take place. In the $1980 \mathrm{~s}$, by contrast, it is other countries that must decide whether the United States is likely to retaliate and how large the penalty might be if it does. The Smoot-Hawley analysis suggests that the United States can encourage its trading partners to pursue the negotiation-open markets strategy by making the economic losses of retaliation large and by convincing its trading partners that it will in fact retaliate. The recent actions taken by the United States in the Canadian lumber, European Community luxury edibles, and Japanese semiconductor cases may represent ways of signaling that the United States will retaliate and that the stakes are high.

President Reagan instituted his trade policy "Strike Force"' in September 1985. Since then, the administration has aggressively interpreted existing trade legislation, and Congress has tightened other legislation. The first effect has been to confuse U.S. trading partners, whose heretofore acceptable domestic or external policies are now inviting retaliation. The U.S. change in stance may encourage its trading partners to review their own trade policies and strategies. One result could be an increased level of more specific and more politically motivated protection in the United States and abroad with a concomitant greater potential for retaliation as consensus about the standard of international trade behavior breaks down. Another could be greater negotiation (in the Uruguay Round, for example) and possibly a new consensus with a more open markets strategy being pursued by all. To what extent can the U.S. conduct of trade policy affect the outcome? First, the United States can make clear that the payoffs have changed. Second, it can make clear that its trade strategy has changed.

When countries sign the GATT, they agree to a standard of international behavior regarding emergency protection and offsetting penalties for certain domestic policies. Moreover, even when emergency protection is allowed and "fair," it must follow the GATT principles of transparency, nondiscrimination, and market orientation. Article XIX, the safeguard clause, outlines the emergency situations that allow temporary protection for specific industries and details the rules of compensation for imposing any protection. Articles VI and XVI, countervailing duty, antidumping, and export subsidy rules, suggest what domestic and external policies can elicit offsetting duties by another country. These rules of the game are not binding and are neither clear nor comprehensive. But the signatories to the GATT have agreed to 
these ideas in principle and have agreed to bring disputes over their implementation to the GATT under Article XXIII, dispute settlement. The articles of GATT, therefore, represent a relatively stable consensus on what trade policies are grounds for penalties but not for escalating retaliation. Moreover, applying protection allowed under the GATT does impose a discipline. As Gardner Patterson puts it, "An important cost of discrimination .... [is] the necessity of reporting on it and defending it periodically in semi-public forums before an essentially hostile audience." 26

The United States has close analogues to the GATT articles in its own trade laws. Section 201 of the Trade Act of 1974, the so-called escape clause, allows emergency protection of industries injured by imports. The countervailing and antidumping statutes allow offsetting penalties for a wide variety of foreign policies. But the United States also has Section 301 of the Trade Act, which allows the president to act against the imports of any country that the ITC finds to be using policies that restrict U.S. exports.

Since 1985, the United States has become much more aggressive in its definition of policies that can elicit penalties. Both the administration and Congress are interpreting U.S. trade law and GATT articles much more broadly. The administration has reopened trade cases closed several years ago. It has unilaterally expanded the list of external and domestic policies eliciting "fair" CV/AD penalties. It has leveraged the CV/AD statutes with Section 301 to try to gain market access for U.S. exports in foreign markets. It also has negotiated numerous voluntary restraint agreements and other creative agreements that probably run counter to the GATT principles of transparency and nondiscrimination. Following are a number of specific cases of these kinds.

The administration closed the Canadian lumber case three years ago when the ITC found no injury and the Commerce Department found no dumping and no subsidies to production. In the intervening years, Canadian stumpage policy, which the U.S. industry charged is a subsidy, has not changed. ${ }^{27}$ Yet when the case was reopened last year, Commerce found a subsidy and the ITC found injury. The United States threatened

26. Gardner Patterson, Discrimination in International Trade Policy: The Policy Issues, 1945-1965 (Princeton University Press, 1966), p. 38.

27. Stumpage fees are the price of a right to cut lumber on government land. 
a 15 percent countervailing duty, but Canada chose instead to levy an export tax of the same amount. More important, Canada, feeling that reopening the lumber case constituted trade harassment, applied a countervailing duty on U.S. corn imports, charging that U.S. farm policy subsidizes corn. It was the first case ever of a countervailing duty on U.S. farm products. The case smacks of tit-for-tat retaliation, and the demonstration value of the Canadian duty is larger than the small volume of Canadian corn imports would suggest. In terms of the game-theory paradigm, the closed markets outcome resulted probably because Canada considered the economic losses of retaliation significantly smaller than the political gains.

Another case is the recent U.S.-European Community (EC) dispute over EC enlargement. Upon joining the EC, Spain and Portugal redirected to France annual purchases of about $\$ 400$ million of U.S. grain, a practice permitted under GATT rules. The United States retaliated for this loss of export markets with 200 percent prohibitive tariffs on a variety of EC luxury edible exports such as wine, cheese, ham, and gin. Hours before the tariffs were to take effect, the United States and the EC negotiated an agreement that allows U.S. grain exporters to compete with community producers for part of the Spanish market. In this case, it appears that the threat of prohibitive tariffs raised the economic stakes sufficiently to encourage a negotiation-open markets strategy. Also, imposing the tariffs, and then giving the $\mathrm{EC}$ an opportunity to negotiate them away, increased the perception that the United States was serious.

The U.S.-Japan semiconductor accord of July 1986 and the more recent imposition of tariffs on certain Japanese electronics is another interesting case. Following an affirmative finding of dumping of certain kinds of semiconductor chips, the United States and Japan negotiated an agreement designed first to reduce the flood of chips into the United States, second to increase the price of chips without differentially hurting U.S. users of chips, and third to enhance the position of U.S. chipmakers in Japanese markets. In order to meet the second objective, the U.S. did not want simply to apply dumping duties. Instead, the accord appears to come close in spirit to fixing the world price for certain kinds of chips. ${ }^{28}$

28. The Commerce Department, using Japanese production cost data, decides on a "fair" price for Japanese chips that includes an 8 percent profit. The Japanese government must then monitor its industries' compliance with this export price. 
The Commerce Department has since charged the Japanese government with failing to monitor export prices, thus allowing chips to be dumped through third markets. The administration imposed 100 percent tariffs on $\$ 300$ million of Japanese electronic products such as laptop computers, certain television sets, and power-driven hand tools. Coincidentally, some of the affected firms have U.S. competitors that have been trying to crack the Japanese market. The tariffs come at a time when Japanese producers are particularly vulnerable in the U.S. markets because of the yen appreciation; Korean and Taiwanese producers are ready to step in. Therefore, it appears that the Commerce Department's retaliation for the Japanese government's nonperformance on the chip agreement could impose some economic losses on Japan. Although the tariffs have been imposed, Commerce has said that they will be rescinded as soon as Japan can prove that it is not dumping chips into third markets. Thus, as in the luxury edibles case, there is an opportunity for the United States and Japan to reach the negotiated outcome. But this negotiated outcome might not have been possible had the United States not shown that it is serious about retaliation, which in turn raises the probability Japan puts on the losses associated with a trade war.

Various aspects of the semiconductor case have been brought to the GATT. The EC has filed a case arguing the illegality of the semiconductor accord. Even though the accord appears to be nondiscriminatory, it certainly does not meet the market test required of GATT-approved methods of protection. Moreover, Japan threatens to file in the GATT for compensatory damages, arguing that in fact it has met the terms of the agreement. If so, the U.S. tariffs may come under Article XIX, which allows the affected country to apply compensating tariffs.

Other examples of a change in U.S. policy stance can be found in Section 201 cases, in which Congress has loosened the requirements for obtaining an affirmative judgment of injury from the ITC. Changes include relaxing the requirements that imports be the most important cause of injury and that injury be measured primarily by changes in employment. Now, imports need be only one of several causes, and the ITC must measure injury much more broadly than simply by changes in employment. With the new legislation in place, the nonrubber footwear case turned from a no-injury decision in 1983 to a vote of injury in 1985. Under existing law, the president need not abide by the ITC recommendations, and in the footwear case, President Reagan vetoed any protec- 
tion. That presidential discretion is one loophole Congress is aiming to close.

In another example of how the United States is signaling its intention to play hardball in the trade policy game, the administration has begun to use Section 301, "unfair trade practices," as a threat to open export markets. If a country is found to be unfairly closing markets to U.S. exports, the president can retaliate against any product exported from that country. This rather broad mandate has led to agreements opening the Korean insurance market and the Japanese tobacco market, the latter of which involves removing a 26 percent tariff and restructuring the domestic tobacco monopoly. In two cases, one against Japanese rice producers and the other against Argentine soybean producers, the president has used the discretion with which he is currently empowered and refused to act. Again, Congress wants to eliminate that discretion. Moreover, the omnibus trade bills expand the definition of unfair trade practices to include such issues as workers' rights and targeting of traditional U.S. overseas markets.

An interesting problem involving these negotiated 301 settlements is cheating. ${ }^{29}$ In the Korean insurance case, for example, the initial settlement apparently opened the market. But U.S. companies were not initially allowed to participate in a compulsory financing pool, so a second case was threatened. In a Japanese telecommunications case, the United States charged the Japanese with unfairly limiting competition in the telecommunications market because Nippon Telephone and Telegraph (NTT) was a government entity. The Japanese government agreed to take NTT public, and it is now a public corporation, all of whose shares are owned by the government.

The Reagan administration is also using other existing legislation more extensively in the trade arena, applying Section 232 (national security) to products ranging from machine tools to frozen concentrated orange juice. Taiwan and Japan agreed to voluntary export restraints on machine tools, perhaps because they are used to having this kind of policy "negotiated," and after all, they do get the economic rents for their trouble. Switzerland and Germany did not agree to such restraints.

29. Cheating can be put into the game-theory paradigm by making payoffs a weighted average of the cheat and no-cheat values. However, the repeated game format is a necessity for this model to make sense. 
Because Swiss and German machine tools do not compete with U.S. products, the two countries argued that the U.S. threat was politically motivated, that voluntary restraints run counter to GATT rules, and that they would not be party to any such agreements. The president has threatened to slap quotas on their machine tools if their exports to the United States exceed a specified level.

Collectively these actions seem to signal a shift in U.S. trade policy. Even so, U.S. behavior is hard to predict. Moreover, the costs of retaliation are hard to quantify. In some of the specific cases noted above, threats of U.S. retaliation apparently led to negotiations to open markets. In others, it appears that tit-for-tat retaliation strategy is being pursued. Therefore, the United States cannot be sure that its threats of retaliation will lead to other countries choosing the open markets strategy.

For that reason the United States is engaged in both multilateral and bilateral negotiations to increase the economic gains from an open markets strategy and to increase the likelihood that other countries will pursue that strategy. The GATT Uruguay Round brings to the table many topics and many countries. On a smaller scale, the United States has negotiated a free trade agreement with Israel and is negotiating one with Canada. There is also mention of trade agreements with areas ranging from Mexico to the Southeast Asian nations. Together, these two negotiation techniques may be the best way to maximize the likelihood of the open markets strategy being pursued by all.

\section{Conclusions}

An examination of the macroeconomic, political, and institutional environment of the 1930s and the 1980s reveals certain circumstances that lead to trade tensions and incidents of trade retaliation. Periods of macroeconomic stress, especially when linked to external events such as trade imbalances, decrease the political benefits to the United States of following a liberal and open markets trade policy. During these periods, Congress, with its regional constituency, may be relatively more powerful than is the president, with his national constituency. The shifting balance of power may further undermine support for free trade. As a result, the conduct of U.S. trade policy becomes somewhat difficult 
for trading partners to predict. Moreover, in reexamining its commitment to free trade, the United States may change its response to foreign policies, deviating not only from its established behavior, but from the consensual international code of trade conduct.

These stylized relationships between macroeconomic environment and political and institutional pressures can be analyzed in a simple game-theory paradigm, in which changes in the environment and balance of political power change the elements of a payoff matrix. But trading partners may be uncertain both about the magnitudes of the payoffs and about the likelihood of the United States making good on its trade threats. They may not be sure whether U.S. policy has actually changed or whether political posturing and threats are just camouflage. Trading partners therefore must choose a trading strategy based on expected value of payoffs. This uncertainty can result in an ex post suboptimal choice of trade strategy, possibly forcing retaliation.

Examining instances of trade tensions and trade retaliation from the 1930s and the 1980s in light of the simple game-theory paradigm gives some support for pursuing this analytical construct further. The policy implications of the model are that the United States should, subject to the restrictions of a democracy, make clear both the direction of its trade policy and the magnitudes of any penalties. Much of the tit-for-tat trade retaliation observed in recent months may represent just such an effort to communicate. 